\title{
The Impact of Community Based Health Insurance Scheme on Health Care Utilization in North Achefer Woreda, West Gojjam Zone, Amhara Region, Ethiopia
}

\author{
Lesanework Alemu Abenet, Bamlaku Alamirew Alemu, Migbaru Alamirew
}

\begin{abstract}
Many countries are being challenged to meet Universal Health Coverage (UHC) because of their weak health systems, poor quality of health services and insufficient financing capacity. Ethiopia has implemented community-based health insurance to reduce households` cost they expend for health care and to scale up service utilization. To assess the impact of the community-based health insurance on health care service utilization of households in North Achefer Woreda, West Gojjam Zone, Amhara region, Ethiopia. The study used cross-sectional household survey data both from CBHI members and non-members. The study used clustering method to select the sample kebeles and random sampling method to select the respondents. For qualitative data, focus group discussions and key informants' interviews has been applied. Descriptive statistics and econometric models such as PSM and ESR have been used to analyze the data. The result of PSM shows that households who enrolled in CBHI scheme have 1.05 to 1.35 more frequency visits and $5.4-7.5$ percent more awareness on family planning than notenrolled households. It also depicts that non-CBHI enrolled households have from 11.83 birr to 17.96 birr more monthly health care expenditure than treated groups. But PSM does not account for endogeneity and self-selection bias in participating in CBHI scheme, so that ESR results are more robust and reliable. For households participating in CBHI scheme, the expected average frequency of visit of them would have been less by 0.89 , their expected average monthly expenditure would have been 7.9 birr more and their awareness on family planning would have been less by 13.1 percent, if they did not enroll to the scheme.
\end{abstract}

Index Terms - Health care utilization, Health care expenditure, CBHI, PSM, ESR, North Achefer Woreda

\section{INTRODUCTION}

Well-functioning financing system of countries highly affects the peoples' health utilization capacity by determining the existence of services and their ability to pay for the health services they need (World Health Organization, 2010). The World Bank (WB) has developed two major targets globally to measure financial protection and health service delivery coverage improvements. These are (a)reducing the number of impoverished people due to out of pocket payments for health care payments by half by 2020 and making zero by 2030 and (b) creating access to basic health services for $80 \%$ of lowest income people in all countries.

Ethiopia has implemented health insurance schemes: social health insurance for formal sector employees and pensioners, and community-based health insurance for informal sector. These schemes are hopeful in reducing financial risks and mobilizing resources for the health sector. As a result, Ethiopian Health Insurance Agency (EHIA) has been established to lead the health insurance schemes and is strengthening its capacity and opened branch offices across the country. Community based health insurance was piloted in thirteen woredas of four regional states, Oromia (4 woredas), Amhara (3 woredas), SNNPs (3 woredas) and Tigray (3 woredas), in 2010/11. The new directive and scale up strategy was developed at the national level which enabled to increase the number of woredas to 191 . Currently about 2,372,736 (35.7\%) households joined CBHI, that becomes 36\% average achievement.

Ethiopian health facilities admission reports indicated that establishment of health facilities to address universal health care coverage to the communities is expanded across all regions, zones and Woredas of the country low health care service utilization. The people`s expenditure for health services has grown but the utilization trend remained low. Specifically, women and poor people (under poverty line) had lower utilization reports on modern health care services(FMOH, 2014) (WHO, 2015) (Bazie \& Adimassie, 2017). 


\section{International Journal of Research in Advent Technology, Vol.7, No.11, November 2019 E-ISSN: 2321-9637 \\ Available online at www.ijrat.org}

The Ethiopian health care expenditure per capita was $\$ 73.00$ in 2014 which is nearly 4.9 percent of their GDP. Although health care financing has improved significantly over the years as a result of the health care financing strategy, inadequate health care financing remains a major challenge for the health system of the country (FMOH, 2014) (WHO and World Bank, 2017).

Studies conducted on the area have come up with the results that indicated that community based health insurance has increased health access, household welfare and health service utilization (Escobar, Griffin, \& Shaw, 2010) (Jutting, 2001) (Ethiopian Health Insurance Agency, 2015) (Yilma, et al., 2014) (Mebratiea, Sparrow, Alemu, \& Bedi, 2013).

The health service access to the peoples determined by different factors, such as sex, age, wealth, literacy level, distance from the health facilities, ethnicity, religion and other socio-economic factors. The health utilization status of households increases when the income and level of education increases. Households who have health insurance utilize better than households without insurance and any type of health insurance makes health care access easier (World Health Organization, 2013), (Raiz, et al., 2016). The direct and indirect costs of health services, access to health facilities, health seeking behavior, inability to pay for the services, perception that the illness is not severe, proximity to facilities and selfmedications, poor services and cultural issues also influence health service utilization behavior of the community (FMOH, 2014)

CBHI is incorporated to UHC strategies of low- and middle-income countries because it provides great importance in targeting and enrolled underserved, uninsured, and largely informal-sector populations into risk-pooling schemes (Wright, et al., 2016).

$\mathrm{CBHI}$ is a program having voluntary nature which helps to mitigate risks to cover full or some part of health service costs. It is mainly designed to address the informal sector (the community). It is simple to use, accessible, self-manageable and has revenue generating capacity and reflects principles of solidarity (Tabor, 2005), (Jakab \& Krishnan, 2001). The premiums of CBHI program are community rated, independent of household incomes and prepaid which can significantly reduce out of pocket for those who joined the scheme (Mathauer, Mathivet, \& Kutzin, 2017). Community financing enhances the poor people to access of health care services by reducing out-of-pocket spending. Even if, it offers financial protection to the poorer, it may exclude the very poorest sections of the population due to their inability to pay premiums (Preker, et al., 2002), (Ekman, 2004).

In addition to accessing health care services and reducing catastrophic expenses, CBHIs are important to improve the quality of health care services (improve drug and medical supply, availability, quick and appropriate responses to patients) and to mobilize revenues for health care providers. It can also increase the utilization capacity of health care providers (Tabor, 2005).

The demand of households for CBHI is affected by their income and probability of being sick. It is also influenced by awareness and knowledge about the scheme, age of house hold head, marital status of head, timing and modality of premium collection, rules and regulations to manage the scheme, quality of health services, enrollment process, benefit package, distance to health facilities, provider attitude, provider choice, trust on CBHI officials, education status, attitude towards traditional health care and proportion of children in households (Panda, et al., 2016), (Umeh \& Feeleya, 2017).

In addition to promoting of equitable access to health care services, it is critical to ensure.

Universal Health coverage (UHC) brought health improvements such as better access to necessary care and improved population health, with the largest gains ensuing to poorer people and it is powerful way for improving women's health in a number of low- and middle-income countries including Afghanistan, Mexico, Rwanda and Thailand (Nicholson et al 2015).

The study conducted in Greece showed that health care utilization was higher for people who moderate and poor self-rated health, older people, women. Income level and region determine frequency of hospitalization (Geitona, Zavras, \& Kyriopoulos, 2007). Individuals socioeconomic status, illness type and region of residence affected the health care utilization, household economic level and distance from health facility determined the magnitude of health care cost in Zambia (Masiye \& Kaonga, 2016). Furthermore, the study conducted in South Africa revealed that quality of public health services as a major reason to affect health care utilization and being immigrant and people without insurance have lower frequency of visit (Abaerei, Ncayiyana, \& Levin, 2017). According to the study in North East Ethiopia, Females, annual income greater than poverty line, poor self-rated health, high perceived severity of illness, the existing of more than two ill members of the family and 


\section{International Journal of Research in Advent Technology, Vol.7, No.11, November 2019 E-ISSN: 2321-9637 \\ Available online at www.ijrat.org}

presence of chronic patient have higher number of visits to health facilities (Bazie \& Adimassie, 2017)

The Rwandan government offered CBHI plan with high level political support and has made health insurance obligatory for everyone. It also introduced performance based financing which improved quality of health services thereby $90-95 \%$ of the informal sector is enrolled in CBHIs. This resulted, the deliveries at health facilities increased by $78 \%$, new curative consultations by $51 \%$, and family planning users by $209 \%$ from 2005 2011 (Humuza, 2011).

In addition, the study conducted in Rwanda 2015 depicted that the rate of utilization of health services including demand for consultations was higher for newly insured than who remained uninsured. This study was conducted in three piloted areas and indicated that probability of enrolled in insurance scheme was equal among all income groups, patients' gender and age. But households' distance from the facilities (inversely related) and awareness on the scheme (positively affected it), family size (the higher the number, the greater the probability to join), education status (positively affect it), geographic access to the health facility and health status determined their probability to join the scheme. The scheme also improved the financial access and reduced out of pocket payments of members substantially especially for women, children, and the poor. However, the scheme has wiped out the poorest (Kalisa, Musange, Collins, Saya, \& Kunda, 2015).

The study in Senegal showed that CBHI members' probability of visiting health care facilities increases by $2 \%$ and OOP reduced by about 50 percent compared with nonmembers. In addition to CBHI membership, age and gender had a paramount effect on accessing health care services. Women and elderly people used hospital services than young and men and the also relatively paid higher cost for the services. The CBHI schemes in Senegal indicated that it is possible to enroll the rural households in health insurance schemes and address a better access to health care for left out people (Jutting, 2001).

The three surveys conducted on the selected Asia and Africa regions hinging up on their community financial arrangements and experiences found that members of community financing schemes reported higher use of health care services and had lower out-of-pocket expenditures thereby confirmed the hypothesis prepayment and the pooling of risk reduced financial barriers to health care. However, the ability to pay additional out of pocket charges and being poor were still challenges for members to access (Preker, et al., 2002).

According to the systematic review conducted in 2013 (Mebratiea, Sparrow, Alemu, \& Bedi, 2013) showed that 74 percent of the studies (26 out of 35 ) concluded CBHI membership had paramount effects on access to health care utilization. The effect on outpatient care was $75 \%$ (the magnitude of insured vs uninsured ranged from 4.3 to $10.5 \%$ ) and on inpatient was $64 \%$ (the magnitude of insured vs uninsured ranged from 1.1 to $6.9 \%$ ). With regarding out of pocket payments, 56 percent of studies concluded that the schemes have significantly reduced OOP healthcare payments.

The Ethiopian Health insurance agency evaluation in 2015 has also identified potential determinants to join CBHI scheme. These are household size; age, education, and sex of the head of household; and size of cultivated land, registration fee, payment schedule and knowledge. Others also needed to see the effect before joining the scheme. According to the study being older and female, having larger family size, more awareness and knowledge of the scheme and literate household heads had positive impact to sign up the scheme. The study showed that the probability of visiting health care services by members was $26.3 \%$ higher than nonmembers, which could be the evidence to scale up CBHI to increase health utilization. The out of pocket payment for health care services while visiting health facilities was relatively higher for non-members than members (Ethiopian Health Insurance Agency, 2015).

On the other hand, health status and household socioeconomic status did not have any effect on joining of the scheme but participating in productive safety net program and quality of health care services were determinants to enroll in the scheme and also to access basic health care services. The outpatient health care utilization of members was increased by $10 \%$ from 2011 2013 but slightly decreased for non-members. But the utilization of non-members was also affected by health providers unbalanced services and treatments. It also showed there was difference in OOP, relatively low for members than non-members (Mebratie, 2015). Health insurance decreases financial barriers and increases access to health care. it has positive impact on maternal health and facility based delivery across all types of insurance schemes in developing countries. The insurance scheme has increased utilization of contraception and reduced unintended pregnancies 


\section{International Journal of Research in Advent Technology, Vol.7, No.11, November 2019 \\ E-ISSN: 2321-9637 \\ Available online at www.ijrat.org}

among low-income American women (Naik, Morgan, \& Wright, 2014).

Studies in the piloted Woredas (Mebratie, 2015) (Ethiopian Health Insurance Agency, 2015) have showed the impact of community based health insurance on health access and utilization as well as how it mitigated financial hardships. But these studies came up with inconsistent results on the determinants of enrollment on the scheme and they used different methodologies that cannot overcome selection bias, didn't account heterogeneity effects and didn't estimate for counterfactuals.

\section{RESEARCH METHODOLOGY}

A. Description of the study area

North Achefer Woreda is one of the woredas in the West Gojjam Zone, Amhara Region of Ethiopia. It is named for the historic district of Achefer, which was first mentioned in the 16th century. Part of the West Gojjam Zone, North Achefer is bordered on the south by South Achefer, on the west by the North Gondar Zone, on the north by Lake Tana, on the east by Bahir Dar Zuria, and on the southeast by Mecha Woreda (one part of Abay River defines the woreda's eastern boundary). The woreda includes Dek Island. The administrative center is Liben; other towns in North Achefer include Yismala and Kunzila. it was part of former Achefer woreda. Based on the 2007 national census conducted by the Central Statistical Agency of Ethiopia (CSA), this woreda has a total population of 189,716 , of whom 96,856 are men and 92,860 women; 15,583 or $8.21 \%$ are urban inhabitants. The majority of the inhabitants practiced Ethiopian Orthodox Christianity, with $99.05 \%$ reporting that as their religion.

According to the data from the Woreda health insurance office, there are about 16,766 households who are members of community based health insurance out of 31,435 total households.

\section{B. Study design and sampling technique}

The total households of North Achefer Woreda is about 31,435 and among these house holds 16,766 households have joined (data from Health Insurance office). The population of the Woreda is clustered in to 7 health centers in order to provide health care services. From the 7 clusters, the study used 2 of them (28\%) and has chosen Liben and Yismala health centers clusters by using the lottery method. These clusters have 5 kebeles each and we chose 2 kebeles from Liben cluster and 3 kebeles from Yismala cluster by using clustering and lottery method.
To identify the sample size for the study, sample size calculation formula is used, which is as follows. $n=N / 1+\left(N e^{2}\right)$

where $\mathrm{n}=$ number of samples, $\mathrm{N}=$ population size, $\mathrm{e}=$ the allowed precession $(5 \%)$

376 households have been used as a sample. Since there was no way to use systematic household selection due to the distribution and composition of households, the study used simple random method to carry out the household survey.

\section{Methods}

The researcher used both quantitative and qualitative data to acquire sufficient information for the study. For quantitative data collection, the researcher has used primary (cross-sectional household survey) data, and for qualitative data collection both Focus Group discussion and interviewing of key informants have been implemented.

The cross-sectional household survey helps to acquire households' health utilization status (how many times they visited health facilities to get health services within the last three months prior to this study) and their monthly health care expenditure. This also helps to identify the factors that held them back not to join community based health insurance or encouraged them to participate in the scheme. The household survey comprised both participants and non-participants of the scheme.

Focus Group Discussions and key informants' interviews help to get the required qualitative data which enriches the information gained from the survey because these discussions are vital in getting of detail information on the area.

\section{Data instrument}

For house hold survey, self-manageable questionnaires have been developed and distributed to respondents. Five data collectors have been trained and deployed to collect the required data. These data collectors are members of health extension workers in the selected kebeles so that they can identify member and non-member households easily.

Focus group discussions and key person interview questions have been prepared and the discussions were based on these questions. Focus group discussions have been undertaken with health professionals with 6 members (2 Health officers, 1 laboratory technician, 1 


\section{International Journal of Research in Advent Technology, Vol.7, No.11, November 2019 E-ISSN: 2321-9637 \\ Available online at www.ijrat.org}

pharmacist, 2 nurses) and with member households (two discussions with 6 and 5 members). Key informants' interviews were also carried out with heads of two health centers and head of the Woreda health insurance office.

\section{E. Data processing and Analysis}

After data collection, the researcher decoded the data in to Microsoft excel and STATA (statistical analysis software). Descriptive and inferential data analysis, and propensity score matching and endogenous switching regression econometric analyses were used to analyze the impact of community based health insurance on health care utilization and monthly health care expenditure. The descriptive statistics used to overview of the data set and described the general characteristics of respondents. Inferential statistics such as t-test and chi square tests were used.

PSM analysis was used to create a statistical comparison group based on the probability of participating in the treatment using observed characteristics. Based on the probability of participating in the treatment group, matching was conducted. Endogenous Switching Regression analysis was also employed, which mainly helps to reduce bias and accounts heterogeneity effect. It can also operate the health care utilizations and expenditures of counterfactuals, which PSM has a limitation on it.

\section{F. $\quad$ Model Specifications}

The study used health utilization (number of visits of health centers) and monthly health care expenditure as final measures for the impact of community based health insurance scheme, that is households' decision to join and participate in $\mathrm{CBHI}$ scheme to maximize their capacity to utilize essential health services.

\section{1) Propensity Score Matching (PSM)}

PSM constructs a statistical comparison group by modeling the probability of participating in the program on the basis of observed characteristics unaffected by the program. Participants are then matched on the basis of this probability, or propensity score, to nonparticipants. The average treatment effect of the program is then calculated as the mean difference in outcomes across these two groups. On its own, PSM is useful when only observed characteristics are believed to affect program participation. This assumption hinges on the rules governing the targeting of the program, as well as any factors driving self-selection of individuals or households into the program. PSM constructs a statistical comparison group that is based on a model of the probability of participating in the treatment $T$ conditional on observed characteristics $X$, or the propensity score: $P(X)=\operatorname{Pr}(T=$ $1 \mid X)$. Rosenbaum and Rubin (1983) showed that, under certain assumptions, matching on $P(X)$ is as good as matching on $X$. The necessary assumptions for identification of the program effect are (a) conditional independence and (b) presence of a common support. Conditional independence states that given a set of observable covariates $\mathrm{X}$ that are not affected by treatment, potential outcomes $\mathrm{Y}$ are independent of treatment assignment T. This assumption is also called un-confoundedness (Rosenbaum \& and Rubin, 1983), and it implies that uptake of the program is based entirely on observed characteristics. If unobserved characteristics determine program participation, conditional independence will be violated, and PSM is not an appropriate method.

A second assumption is the common support or overlap condition: $0<\mathrm{P}(\mathrm{Ti}=1 \mid \mathrm{Xi})<1$. This condition ensures that treatment observations have comparison observations "nearby" in the propensity score distribution (Heckman, LaLonde, \& Smith, 1999). Specifically, the effectiveness of PSM also depends on having a large and roughly equal number of participant and nonparticipant observations so that a substantial region of common support can be found.

To calculate the program treatment effect, one must first calculate the propensity score $\mathrm{P}(\mathrm{X})$ on the basis of all observed characteristics. The aim of matching is to find the closest comparison group from non-participants. These closest units become the comparison group and are used to produce an estimate of the counterfactual. Since propensity score matching is not a randomized assignment method but tries to imitate one, it belongs to the category of quasi-experimental methods. The average difference in outcomes between the treatment or enrolled units and their matched comparison units produces the estimated impact of the program. For propensity score matching to produce estimates of a program's impact for all treated observations, each treatment or enrolled unit needs to be successfully matched to a not-enrolled unit. Based on the propensity score different matching criteria can be used to assign enrolled groups to not-enrolled groups. The first matching technique is nearest neighbor matching, in which each treated unit is matched to the unit in the comparison group that presents the closest estimated propensity score. After matching, the outcome of the treated units is compared with the outcome of matched control units. The second matching technique is caliper matching, which involves matching with replacement, only among propensity scores within a certain range. The third matching technique is stratification or interval matching, it partitions the 


\section{International Journal of Research in Advent Technology, Vol.7, No.11, November 2019 E-ISSN: 2321-9637 \\ Available online at www.ijrat.org}

common support in to different strata or intervals and calculates the impact with in each interval. The fourth matching technique is kernel matching, which assigns higher weight to observations close in terms of propensity score to a treated individual and lower weight to more distant observations.

\section{2) Endogenous Switching Regression Model (ESR)}

The decision to join or not to join in CBHI scheme is voluntary and is based on household's self-selection, it is more of endogenous than exogenous. This model begins by sorting of persons to positions and the effect of positions on outcomes. The allocations of persons to positions is a decision of individual actors. If we use OLS, it may lead us biased estimates. Households that joined the scheme may have different characteristics from households who didn't join the scheme. Unobservable characteristics of households, such as attitude towards the importance of the scheme, may affect their decision to participate and utilization of basic health services (Falco, Veronesi, \& Yesuf, 2010), (Ghimire \& KotaniA, 2015), (Bocher, Alemu, \& Kelbore, 2017). Hence, it is preferable to use endogenous switching regression that helps to jointly conceive the participation in CBHI scheme and health services utilization. It allows us to implement counterfactual experiments to know the impact of CBHI, if noneparticipants participate or if participants not participate.

An endogenous switching regression model follows two steps. In the first step, it models the decision of whether the households joined CBHI scheme or not, and in the second step, it models the outcome of health service utilization (number of visits) depend on households are participants or not-participants. The households are assumed decide to join the scheme based on the expected outcome for health service utilization. The households decide to join the scheme if they expected to access better health service utilization in terms of number visits of health facilities than non-participants.

Let the expected outcomes of household-i obtained by participating and not-participating in $\mathrm{CBHI}$ scheme be $Y_{1}$ and $Y 2$, respectively. Households are assumed to decide to participate in the scheme if $Y_{1}>Y 2$. The selection equation for $\mathrm{CBHI}$ scheme participation is specified as

$T_{i}^{*}=\alpha Z_{i}+\eta_{i}$
Where, $T_{i}^{*}$ is a latent variable that captures expected outcomes from participation decisions by household- $i$, $\mathrm{T}$ is participation status of households, households who decided to join CBHI scheme $(\mathrm{T}=1)$ and Who didn't decide to join (T=0). This implies that $T_{i}=1$ if $T_{i}^{*}>0$ and $T_{i}=0$ if $T_{i}^{*}$ is otherwise, vector $Z_{i}$ represents variables that affect participation decisions such as socio-economic characteristics for household $i, \alpha$ is a vector of parameters to be estimated, and $\eta_{i}$ is a random error term with mean zero and variance $\sigma^{2} \eta$.

To account for selection biases, endogenous switching regression model will be applied where households face two regimes (1) to join and (2) not to join the $\mathrm{CBHI}$ scheme.

Regime 1: $Y_{1 i}=\beta_{1} x_{1 i}+\varepsilon_{1 i}$ if $T_{i}^{*}=1$----- (2)

Regime 2: $Y_{2 i}=\beta_{2} x_{1 i}+\varepsilon_{2 i}$ if $T_{i}^{*}=0$

Where, $\mathrm{Y}_{\mathrm{i}}$, is number of visits of health centers by households of regime 1 and $2, \mathrm{X}_{\mathrm{i}}$, represents independent variables for equation 2 and 3 , variables that affect participation decisions $\beta_{1}$ and $\beta_{0}$ are parameters to be estimated for participants and non-participants, respectively. $\varepsilon_{1 \mathrm{i}}$ and $\varepsilon_{2 \mathrm{i}}$ are random error terms for participants and nob-participants with variances $\sigma^{2}{ }_{1}$ and $\sigma_{2}^{2}$, respectively. The variables in $X_{1}$ and $X_{2}$ should be included in the variable lists of $\mathrm{Z}_{\mathrm{i}}$, in equation 1 and the selection equation should comprise at least one more independent variable than equation 2 and 3 .

The unobservable characteristics of households that determine the choice of CBHI scheme affect the basic health service utilization trends of the households in each regime. Therefore, full information maximum livelihood (FIML) estimation is applied to simultaneously measure selection and regime equations using the endogenous switching regression model that takes account of sample self-selection problems. A series of these estimations for parameters in equations (1) to (3) will be executed in STATA using the "move-stay" command developed by Lokshin and Sajaia (Lokshin \& Sajaia, 2004). Based on the estimates of $\beta_{1}$ and $\beta_{2}$, expectation of health utilizations (number of visits of facilities by households) for both participants and non-participants of CBHI scheme is calculated. The counterfactual values will be calculated by using the estimated $\beta_{1}$ and $\beta_{2}$ by considering participation in CBHI scheme as a treatment. 


\section{International Journal of Research in Advent Technology, Vol.7, No.11, November 2019 \\ E-ISSN: 2321-9637 \\ Available online at www.ijrat.org}

As mentioned above, the endogenous switching regression model is important to compare the expected number of visits of health centers by households that joined the CBHI scheme with respect to the households that did not join the scheme, to investigate the expected health service utilizations in the counterfactual hypothetical cases, that the participating households did not participate and that the non-participating households participate.

Expected number of visits (both outpatient and inpatient) of CBHI member households (Observed) with participating in $\mathrm{CBHI}$ scheme is

$$
E\left(Y_{1 i} / T=1\right)=\beta_{1} X_{1 i}+\sigma_{1 \eta} \lambda_{1 i}
$$

Expected number of visits (both outpatient and inpatient) of CBHI member households without participating in CBHI scheme (Counterfactual) is

$$
E\left(Y_{2 i} / T=1\right)=\beta_{2} X_{1 i}+\sigma_{2 \eta} \lambda_{1 i}
$$

Expected number of visits (both outpatient and inpatient) of non-CBHI member households without participating in CBHI scheme (Observed) is

$$
E\left(Y_{2 i} / T=0\right)=\beta_{2} X_{2 i}+\sigma_{2 \eta} \lambda_{2 i}
$$

Expected number of visits (both outpatient and inpatient) of non-CBHI member households with participating in CBHI scheme (Counterfactual) is

$$
E\left(Y_{1 i} / T=0\right)=\beta_{1} X_{2 i}+\sigma_{1 \eta} \lambda_{2 i}
$$

The average treatment on treated (ATT) is the difference between number of visits (both outpatient and inpatient) (Observed) and its counterfactual of CBHI member households and the average treatment on untreated (ATU) is calculated as the difference between number of visits (both outpatient and inpatient) (Observed) and its counterfactual of non-CBHI member households.

$$
\begin{aligned}
& \operatorname{ATT}=\left(E\left(Y_{1 i} / T=1\right)-\left(E\left(Y_{2 i} / T=1\right)\right)=\left(\beta_{1} \mathrm{X}_{1 \mathrm{i}}\right.\right. \\
& \left.+\sigma_{1 \eta} \lambda_{1 \mathrm{i}}\right)-\left(\beta_{2} \mathrm{X}_{1 \mathrm{i}}+\sigma_{2 \eta} \lambda_{1 \mathrm{i}}\right) \\
& \quad=\left(\beta_{1}-\beta_{2}\right) \mathrm{X}_{1 \mathrm{i}}+\left(\sigma_{1 \eta}-\sigma_{2 \eta}\right) \lambda_{1 \mathrm{i}----}(8)
\end{aligned}
$$

It represents the actual effect of CBHI scheme on health service utilization of households who actually joined (participating in) the scheme.

$\mathrm{ATU}=\mathrm{E}\left(\mathrm{Y}_{2 \mathrm{i}} / \mathrm{T}=0\right)-\left(\mathrm{E}\left(\mathrm{Y}_{1 \mathrm{i}} / \mathrm{T}=0\right)=\left(\beta_{2} \mathrm{X}_{0 \mathrm{i}}+\sigma_{2 \eta} \lambda_{2 \mathrm{i}}\right)-\right.$ $\left(\beta_{1} \mathrm{X}_{2 \mathrm{i}}+\sigma_{1 \eta} \lambda_{2 \mathrm{i}}\right)$

$$
=\left(\beta_{2-} \beta_{1}\right) X_{2 i}+\left(\sigma_{2 \eta}-\sigma_{1 \eta}\right) \lambda_{2 i---~}(9)
$$

It represents the actual effect of CBHI scheme on health service utilization of households who actually did not join (not participating in) the scheme.

We can use the expected outcomes described in (4) - (7) to calculate also the heterogeneity effects. For example, the CBHI scheme participants may have more visits than households that did not participate regardless of the fact that they decided to participate but because of unobservable characteristics. In this case, participating in CBHI scheme is defined as "the effect of base heterogeneity $(\mathrm{BH})$ " for the group of households that decided to participate as the difference between (4) and (7).
$\mathrm{BH}_{1}=\mathrm{E}\left(\mathrm{Y}_{1 \mathrm{i}} / \mathrm{T}=1\right)-\left(\mathrm{E}\left(\mathrm{Y}_{1 \mathrm{i}} / \mathrm{T}=0\right)=\left(\beta_{1} \mathrm{X}_{1 \mathrm{i}}+\sigma_{1 \eta} \lambda_{1 \mathrm{i}}\right)-\left(\beta_{1} \mathrm{X}_{0 \mathrm{i}}\right.\right.$ $\left.+\sigma_{1 \eta} \lambda_{0 \mathrm{i}}\right)$

$$
=\beta_{1}\left(X_{1 \mathrm{i}}-\mathrm{X}_{2 \mathrm{i}}\right)+\sigma_{1 \eta}\left(\lambda_{1 \mathrm{i}}-\lambda_{2 \mathrm{i}}\right) \text {----- (10) }
$$

For the group of households that decided not to participate, "the effect of base heterogeneity" is the difference between (5) and (6).

$$
\begin{aligned}
& \mathrm{BH}_{2}=\mathrm{E}\left(\mathrm{Y}_{2 \mathrm{i}} / \mathrm{T}=1\right)-\left(\mathrm{E}\left(\mathrm{Y}_{2 \mathrm{i}} / \mathrm{T}=0\right)\right)=\left(\beta_{2} \mathrm{X}_{1 \mathrm{i}}+\sigma_{2 \eta} \lambda_{1 \mathrm{i}}\right)- \\
& \left(\beta_{2} \mathrm{X}_{2 \mathrm{i}}+\sigma_{2 \eta} \lambda_{2 \mathrm{i}}\right) \\
& \quad=\beta_{2}\left(\mathrm{X}_{1 \mathrm{i}}-\mathrm{X}_{2 \mathrm{i}}\right)+\sigma_{2 \eta}\left(\lambda_{1 \mathrm{i}}-\lambda_{2 \mathrm{i}}\right) \text {-------- }(11)
\end{aligned}
$$

Finally, the "transitional heterogeneity" (TH) will be investigated, that is if the effect of CBHI scheme is larger or smaller for the households that participate or for the households that actually did not participate in the counterfactual case that they did participate, that is the difference between equations (10) and (11) (i.e., (TT) and (TU)). The yellow colors (diagonals) are observable effects of CBHI on health service utilization (number of visits both out-patient and inpatient) and the light black colors (diagonals) are the counterfactuals of participants and non-participants in CBHI scheme.

\section{Table 1: Conditional actual and counterfactual} expected frequency of visit

\begin{tabular}{|c|c|c|c|}
\hline & $\mathrm{Y}_{1 \mathrm{i}}$ & $\mathrm{Y}_{2 \mathrm{i}}$ & $\begin{array}{c}\text { Treatment } \\
\text { effects }\end{array}$ \\
\hline $\mathrm{T}=1$ & $\mathrm{E}\left(\mathrm{Y}_{1 \mathrm{i}} / \mathrm{T}=1\right)$ & $\mathrm{E}\left(\mathrm{Y}_{2 \mathrm{i}} / \mathrm{T}=1\right)$ & $\mathrm{ATT}$ \\
\hline $\begin{array}{c}\text { Heterogeneity } \\
\text { effects }\end{array}$ & $\mathrm{E}\left(\mathrm{Y}_{1 \mathrm{i}} / \mathrm{T}=0\right)$ & $\mathrm{E}\left(\mathrm{Y}_{2 \mathrm{i}} / \mathrm{T}=0\right)$ & $\mathrm{ATU}$ \\
\hline & $\mathrm{BH} 2$ & $\begin{array}{c}\mathrm{TH} \text { (ATT- } \\
\text { ATU) }\end{array}$ \\
\hline
\end{tabular}




\section{International Journal of Research in Advent Technology, Vol.7, No.11, November 2019 \\ E-ISSN: 2321-9637 \\ Available online at www.ijrat.org}

Where, BHi: the effect of base heterogeneity for households that participated $\left(\mathrm{BH}_{1}\right)$, and did not participate $\left(\left(\mathrm{BH}_{2}\right)\right.$;

\section{RESULTS AND DISCUSSIONS}

\section{A. Descriptive statistics}

\section{1)Households' characteristics}

There were about 78 percent of male headed and 22 percent of female headed HHs in the sample. Of the total number of enrolled HHs, 73 percent HHs were male headed and from the not-enrolled HHS, 83 percent of them were Male headed. The average age of household head in the study sample of 376 was 45 , and 51 percent of the sample can read and write. The average household size in the survey was 5.3 with 2.6 males and 2.7 female members. In average, there were about 0.7 under five children, 1.7 between 5 and 17 years old, 2.8 between 18 and 64 years old and 0.1 above 64 years old family members live in the one $\mathrm{HH}$. On average, 67,80 and 79 percent of the households in the study responded that they had significant roles in political, social and religious positions, respectively. The average livestock and asset ownership (ETB) of the sample was 40,361 and 4,747, respectively. In the study, the mean annual income (ETB) of the sample was 24, 203 with a significant gap between minimum value, 0 and maximum value, 155,000. Among the respondents, 17 percent responded that they had no cropland and 8 percent of the sample owned 4 and
$\mathrm{TH}=(\mathrm{TT}-\mathrm{TU})$, i.e., transitional heterogeneity

Table 2: definition and description of socio-demographic variables

\begin{tabular}{|c|c|c|c|c|}
\hline Variables Description & Mean & SD & Min & $\operatorname{Max}$ \\
\hline sex of HH head ( 1 if male, 0 if female) & 0.78 & 0.41 & 0 & 1 \\
\hline age of $\mathrm{HH}$ head & 44.57 & 11.59 & 20 & 90 \\
\hline marital status of $\mathrm{HH}$ head ( 1 if married, 0 if otherwise) & 0.82 & 0.39 & 0 & 1 \\
\hline literacy level of HH head ( 1 if can read and write, 0 if not) & 0.51 & 0.50 & 0 & 1 \\
\hline religion of $\mathrm{HH}$ head & 1.00 & 0.00 & 1 & 1 \\
\hline family size of $\mathrm{HH}$ & 5.30 & 2.32 & 1 & 15 \\
\hline HH members' political participation status ( 1 if participating, 0 if not) & 0.67 & 0.47 & 0 & 1 \\
\hline HH members' social participation status (1 if participating, 0 if not) & 0.80 & 0.40 & 0 & 1 \\
\hline HH members' religious participation status ( 1 if participating, 0 if not) & 0.79 & 0.41 & 0 & 2 \\
\hline
\end{tabular}

Source: own survey, 2018

Table 3: description of asset and income variables

\begin{tabular}{|l|c|c|c|c|}
\hline \multicolumn{1}{|c|}{ Variables Description } & Mean & SD & Min & Max \\
\hline Livestock (ETB) & 40360.60 & 34350.84 & 0 & 193000 \\
\hline Dwelling ownership (1 if owned, 0 otherwise) & 0.95 & 0.21 & 0 & 1 \\
\hline Asset (ETB) & 4747.24 & 7797.16 & 0 & 132850 \\
\hline crop-land (hectare) & 1.54 & 1.22 & 0 & 8 \\
\hline cultivated crop-land & 1.54 & 1.22 & 0 & 8 \\
\hline Annual income (ETB) & 24202.82 & 24155.96 & 0 & 155000 \\
\hline
\end{tabular}




\begin{tabular}{|c|c|c|c|c|}
\hline Variables Description & Mean & SD & Min & $\operatorname{Max}$ \\
\hline Source of drinking water ( 1 if pipe, 0 otherwise) & 0.72 & 0.45 & 0 & 1 \\
\hline toilet facility ( 1 if use toilet facilities, 0 if not) & 0.85 & 0.36 & 0 & 1 \\
\hline
\end{tabular}

Source: own survey, 2018

Table 4: description of health care utilization variables

\begin{tabular}{|c|c|c|c|c|}
\hline Variables Description & Mean & SD & Min & Max \\
\hline self-perception ( 1 if HH perceive they are healthy, 0 if not) & 0.86 & 0.35 & 0 & 1 \\
\hline ill member ( 1 if there was ill member, 0 if not) & 0.68 & 0.47 & 0 & 1 \\
\hline chronic ( 1 if there was chronic patient in the $\mathrm{HH}, 0$ if not) & 0.06 & 0.24 & 0 & 1 \\
\hline Frequency of visit (how frequently the HH visited health facilities) & 2.55 & 1.74 & 0 & 12 \\
\hline travel time to health facilities (hr) & 0.92 & 1.01 & 0 & 7 \\
\hline waiting time to meet health professional (hr) & 2.85 & 4.09 & 0 & 60 \\
\hline quality of service ( 1 if very good, good and fair, 0 if poor and very poor) & 0.74 & 0.44 & 0 & 1 \\
\hline Monthly $\mathrm{HC}$ expenditure of the $\mathrm{HH}$ & 23.75 & 31.91 & 0 & 303.67 \\
\hline trust ( 1 if the $\mathrm{HH}$ trust modern health care than traditional care, 0 if & 0.67 & 0.47 & 0 & 1 \\
\hline
\end{tabular}

Source: own survey, 2018

Table 5: description of CBHI variables

\begin{tabular}{|c|c|c|c|c|}
\hline Variables Description & Mean & SD & Min & Max \\
\hline CBHI (1 if the registered and payed, 0 if for non-members & 0.53 & 0.50 & 0 & 1 \\
\hline Awareness on CBHI ( 1 if the $\mathrm{HH}$ is aware on CBHI, 0 if not) & 0.74 & 0.44 & 0 & 1 \\
\hline $\begin{array}{l}\text { Affordability of premium ( } 1 \text { if the } \mathrm{HH} \text { can afford annual CBHI payment, } 0 \text { if } \\
\text { otherwise }\end{array}$ & 0.74 & 0.44 & 0 & 1 \\
\hline
\end{tabular}

Source: own survey, 2018

\section{i. Enrollment in Community Based Health Insurance (CBHI)}

The scheme is voluntary based and self-selection, and in the study woreda, it is determined in the household level. According to the data from the Health Insurance Office of the Woreda, 16,766 households were enrolled in the scheme out of 31, 435 households. In other words, the woreda had the overall enrollment of 53.3 percent in 2017 . The study sample included 200 members and 176 non-member households. According to the data collected from respondents, they explained their reasons why they enrolled or did not enroll. The reasons for not enrolling in the scheme were: illness and injury does not occur frequently in the household (19 HHs), the payment for the premiums are not affordable $(86 \mathrm{HHs})$, they want to wait in order to confirm the benefits of the scheme from others (47 HHs), they do not know enough about the CBHI scheme (70 HHs), the limited services of health facilities (48 HHs), low quality of health care services (53HHs), the benefit package does not meet their needs (34 HHs) and they don't have confidence on the scheme management (11 HHs).

CBHI scheme enrolled HHs have also put their reasons for their choice to be a member. These are illness and injury occurs frequently in their $\mathrm{HH}$ (50HHs), their HH members need health care (122 $\mathrm{HHs}$, to finance health care expenses (163 HHs), Premium is low compared to the user fee price to obtain medical treatment (89 $\mathrm{HHs),} \mathrm{pressure} \mathrm{from}$ other family members/community (16 HHs) and pressure from the kebele/tabia administration (33 $\mathrm{HHs}$ ).

Table 6 provides data on the mean difference test of variables in the model. It compares averages of continuous variables and proportions of binary variables. There is a statistically significant mean difference between households' resources and characteristics based on CBHI enrollment status, except annual income of households. Household heads who enrolled in CBHI scheme are older, can better read and write, have more family members, are more likely to participate in political, social and religious positions, have more livestock (birr), asset and crop land, and have relatively short distance from health facilities than households who did not enroll in the scheme. 
International Journal of Research in Advent Technology, Vol.7, No.11, November 2019

E-ISSN: 2321-9637

Available online at www.ijrat.org

Table 6: Comparison of mean differences of covariates in terms of CBHI membership

\begin{tabular}{|c|c|c|c|c|c|c|}
\hline \multirow{2}{*}{ Variables } & \multicolumn{2}{|c|}{ Means } & \multicolumn{2}{|c|}{ Variances } & \multirow[t]{2}{*}{$t$-statistics } & \multirow{2}{*}{$\begin{array}{l}\text { Significannce } \\
\text { level }\end{array}$} \\
\hline & Control & Treated & Control & Treated & & \\
\hline sex & 0.73 & 0.83 & 0.20 & 0.14 & -2.29 & At 5 percent level \\
\hline age & 43.38 & 45.62 & 160.02 & 110.02 & -1.88 & $\begin{array}{l}\text { At } 10 \text { percent } \\
\text { level }\end{array}$ \\
\hline Marital status & 0.76 & 0.87 & 0.19 & 0.11 & -2.88 & At 1 percent level \\
\hline literacy & 0.44 & 0.57 & 0.25 & 0.25 & -2.37 & At 1 percent level \\
\hline Family size & 4.45 & 6.05 & 4.27 & 5.17 & -7.08 & At 1 percent level \\
\hline $\begin{array}{l}\text { HH political } \\
\text { participation }\end{array}$ & 0.52 & 0.80 & 0.25 & 0.16 & -5.82 & At 1 percent level \\
\hline HH social participation & 0.66 & 0.92 & 0.22 & 0.08 & -6.33 & At 1 percent level \\
\hline $\begin{array}{l}\text { HH religious } \\
\text { participation }\end{array}$ & 0.64 & 0.93 & 0.23 & 0.08 & -7.05 & At 1 percent level \\
\hline Travel time & 1.03 & 0.82 & 1.31 & 0.74 & 1.98 & At 5 percent level \\
\hline Livestock (ETB) & 33834.01 & 46104.00 & $1.26 \mathrm{e}+09$ & $1.04 \mathrm{e}+09$ & -3.51 & At 1 percent level \\
\hline Asset (ETB) & 3758.93 & 5616.95 & $1.64 \mathrm{e}+07$ & $9.85 e+07$ & -2.32 & At 5 percent level \\
\hline Cropland (hectare) & 1.39 & 1.68 & 1.68 & 1.28 & -2.35 & At 1 percent level \\
\hline Annual income (ETB) & 22089.32 & 26062.70 & $7.00 \mathrm{e}+08$ & $4.77 e+08$ & -1.59 & Not significant \\
\hline
\end{tabular}

Source: own survey, 2018

\section{ii. Awareness of HHs on Family planning}

The number of households who have information on family planning are about 94.4 percent. When we enrolled households have knowledge on family planning and from not-enrolled samples, 91.5 percent have information on family planning. There is 5 percent mean difference between enrolled and notenrolled households. The average time (years) the households used one of family planning methods from 353 sample was about 3.5 years and the child spacing they had (among 349 samples, who have children) was about 3 years. The appropriate age of woman to give birth, based on the average data from respondents was 19 years old and 14 percent of the study believed that the appropriate age to give birth to a woman was below 18.

iii. HH's Monthly health care expenditure

The annual payment for the premium, based on the data from the Woreda Health Insurance Office, was as follows. Households who have 5 and below family size payed 144 birr, 6 and 7 family size payed 168 birr, consider the community based health insurance as a comparison variable, 97 percent of the

8 family size payed 192 birr and 9 and above family size payed 244 birr. In addition, some of these households have payed extra money for transport and for health care services. The CBHI scheme has got subsidy from the government and as the report from the Woreda office revealed that there was 1.5-millionbirr loss in 2016/17 due to the CBHI service. As a result, the annual premium payment has been revised at national level and implemented in 2017/18. The 3 months' history, prior to the study, of health service expenditure data of not-enrolled households was collected by the household survey questionnaire. According to the description of the sample, the average monthly health care expenditure of households was 23.75 birr with minimum 0 and maximum 303.67 birr. The average monthly expenditure of enrolled households is 15.12 birr with minimum value of 4.17 birr and maximum value of 


\section{International Journal of Research in Advent Technology, Vol.7, No.11, November 2019 \\ E-ISSN: 2321-9637 \\ Available online at www.ijrat.org}

37.33 birr. On the other hand, the not-enrolled households have average monthly expenditure of 33.57 birr with minimum value of 0 and maximum value of 303.67 birr.

\section{iv. Health care Utilization of HHs}

Health care utilization of households is explained in the study in terms of frequency of visits to health facilities to get health care services. This includes the three months' history, prior to the study time, of both outpatient and impatient health care services utilized by HHs.

Table 7: Description of Family planning variables

\begin{tabular}{|c|c|c|c|c|}
\hline Variables Description & Mean & SD & Min & $\operatorname{Max}$ \\
\hline information on FP ( 1 if the $\mathrm{HH}$ heard about it, 0 if not) & 0.95 & 0.23 & 0 & 2 \\
\hline $\begin{array}{l}\text { perception on importance of FP ( } 1 \text { if the HH perceive it is } \\
\text { important, } 0 \text { if }\end{array}$ & 0.87 & 0.35 & 0 & 2 \\
\hline used FP ( 1 if the HH used, 0 if not) & 0.78 & 0.42 & 0 & 1 \\
\hline for how long $\mathrm{HH}$ used & 3.51 & 2.85 & 0 & 15 \\
\hline child spacing & 3.12 & 0.74 & 1 & 4 \\
\hline appropriate age of woman to give birth & 19.2 & 2.61 & 12 & 28 \\
\hline
\end{tabular}

Source: own survey, 2018

The average frequency of visits to health facilities by the sample was about 2.3. Households who enrolled in CBHI scheme visited 2.8 times within 3 months which is better than not-enrolled households, which is about 1.6.

\section{B.Two-sample t-test on outcome variables before} matching

Whether there is a significant mean difference of health care utilization and expenditure between treated and control groups, two-sampled t-test has been used. Similarly, two-sampled t-test has been employed to check the significant mean difference of independent variables which are used in the model. It is expected to be different before matching and to be balanced (no significant difference) after matching in both treated and control groups.

\section{i. Two-sample t-test on health care utilization (frequency of visit)}

In order to assure if community based health insurance has significant impact on health care utilization, the data was checked by using t-test. According to the evidence from survey, table 8 , the average frequency of visits of community based health insurance enrolled households is 1.21 more than not enrolled households in 3 months. The difference is significant at 1 percent significance level. Hence, enrolled households have better health care utilization than not-enrolled groups.

ii. Two-sample t-test on health care expenditure

Table 9 provides the t-test results which is used to check whether there is a significant mean difference between control and treated groups in terms of monthly health care expenditure. It shows that not enrolled (control) groups have 18.45 birr more health care expenditure than enrolled (treated) groups. The difference is significant at 1 percent significance level. According to the result, enrolling in CBHI scheme reduces the out of pocket payment for health care services, on average by 18.45 birr ( $t$-value $=5.84$ )

iii. Two-sample t-test for family planning awareness Table 10 provides the t-test results which is used to check whether there is a significant mean difference between control and treated groups in terms of awareness on family planning.

Table 8: Average awareness of treated and control groups on family planning. The result shows that the number of CBHI member households who have information on family planning is 5.5 percent more than non-CBHI members. As a result, CBHI members have better awareness than non-members with a statistically significant mean difference $(\mathrm{P}<0.05)$.

Table 9: Average frequency of visit of treated and control groups

\begin{tabular}{|l|l|l|l|l|l|}
\hline Group & Obs. & Mean & Std. Err. & Std. Dev. & t-value \\
\hline Control & 176 & 1.61 & 0.08 & 0.99 & \\
\hline Treated & 200 & 2.82 & 0.12 & 1.75 & \\
\hline diff & & -1.21 & & & -8.09 \\
\hline
\end{tabular}

Source: own survey result, 2018

Table 10: Average monthly health care expenditure of treated and control groups 


\begin{tabular}{|l|l|l|l|l|l|}
\hline Group & Obs. & Mean & Std. Err. & Std. Dev. & t-value \\
\hline Controls & 176 & 33.57 & 3.35 & 44.48 & \\
\hline Treated & 200 & 15.12 & 0.30 & 4.31 & \\
\hline diff & & 18.45 & & & 5.84 \\
\hline
\end{tabular}

Source: own survey result, 2018

Table 10: Awareness on family planning of treated and control groups

\begin{tabular}{|l|l|l|l|l|l|}
\hline Group & Obs. & Mean & Std. Err. & Std. Dev. & t-value \\
\hline Control & 176 & 0.91 & 0.02 & 0.28 & \\
\hline Treated & 200 & 0.97 & .01 & 0.17 & \\
\hline combined & 376 & 0.94 & .01 & 0.23 & \\
\hline diff & & -0.055 & -0.1 & -0.01 & -2.34 \\
\hline
\end{tabular}

Source: own survey, 2018

\section{Econometric estimation results \\ i. Estimating the impact of CBHI on outcome variables: using PSM}

Table 11 presents a regression table by using "psmatch2" which are the regression estimates from the probit model and reports the estimates of the average treatment effect. In this probit model, the dependent variable is enrollment status of households. The observable characteristics of households which are used to estimate propensity scores for matching are sex of $\mathrm{HH}$ head, age of $\mathrm{HH}$ head, literacy level of $\mathrm{HH}$ head, family size, level of $\mathrm{HH}$ political participation, level of $\mathrm{HH}$ social participation, level of $\mathrm{HH}$ religious participation, Livestock ownership (birr), crop land (hectare), Asset (ETB) and Annual income (ETB). As indicated on table 11, the results based on the estimated coefficients shows family size, $\mathrm{HH}$ social participation, $\mathrm{HH}$ religious participation and Asset ownership have significantly affected participation of households in CBHI scheme positively. Households with higher number of family members are more likely to enroll in the scheme than households with less number of family size. Households who engaged in social and religious positions have better involvement in the scheme than those who don't participate in social and religious positions. The households who owned more assets are more likely to participate in CBHI scheme.

When we see the results of "psmatch2" estimation, it provides two results. The first one is the "unmatched" results, it shows the difference between the average frequency of visits for CBHI enrolled households and the average for not enrolled households before matching is taking place. The second result shows the average treatment effect for the treated (ATT), which is the average frequency of visit calculated after matching. the result tells us that enrolling in CBHI scheme has 1.05 more frequency of visits to health facilities than not enrolling in CBHI scheme. On the other hand, the average monthly health care expenditure of control groups is 14.76 birr more than treated groups. Both results are significant at 1 percent significant level, as described below in table 12. The level of awareness of enrolled households is 6 percent more than not enrolled households with 10 percent significant level. Figure 1 shows the comparison of density estimation of both treated and untreated groups before matching and after matching was done.

We estimated the propensity score (pscore) of the treatment on the control variables by using he "pscore" command, which uses a probit (or logit) model and stratifies individuals in blocks according to the pscore. The results include probit regression output, the estimation and description of the propensity scores, the number of blocks and stratification using propensity scores, and the balancing property test. The area of common support is those propensity scores within the range of the lowest and highest estimated values for households in the treatment group.

After balancing is done, estimation of the treatment effect of enrolling in community based health insurance using different matching techniques.

Table 11: probit result of participation in CBHI scheme

\begin{tabular}{|l|c|c|l|}
\hline Covariant & Coef. & Std. Err. & Z \\
\hline Sex & -0.1927406 & 0.1944357 & -0.99 \\
\hline
\end{tabular}


International Journal of Research in Advent Technology, Vol.7, No.11, November 2019

E-ISSN: 2321-9637

Available online at www.ijrat.org

\begin{tabular}{|l|c|c|l|}
\hline Covariant & Coef. & Std. Err. & Z \\
\hline Age & 0.0037273 & 0.0064986 & 0.57 \\
\hline Literacy & 0.0773366 & 0.1619808 & 0.48 \\
\hline family size & 0.1722836 & 0.0375192 & 4.59 (significant at 1\% sig. level) \\
\hline HH political participation & 0.1336168 & 0.1936291 & 0.69 \\
\hline HH social participation & 0.4335658 & 0.2435346 & 1.78 (significant at 10\% sig. level) \\
\hline HH religious participation & 0.670863 & 0.240995 & 2.78 (significant at 5\% sig. level) \\
\hline Livestock ownership (ETB) & $-2.21 \mathrm{E}-06$ & $2.56 \mathrm{E}-06$ & -0.86 \\
\hline Cropland (hectare) & 0.0932471 & 0.0792862 & 1.18 \\
\hline Asset (ETB) & 0.0000315 & 0.0000186 & 1.69 (significant at 10\% sig. level) \\
\hline Annual income (ETB) & $3.26 \mathrm{E}-07$ & $4.02 \mathrm{E}-06$ & 0.08 \\
\hline _cons & -2.061565 & 0.365585 & -5.64 \\
\hline LR chi2(11) & 91.31 & & \\
\hline Prob > chi2 & 0.000 & & \\
\hline
\end{tabular}

Source: own survey result, 2018

Table 12: ATT with in the common support region

\begin{tabular}{|l|c|c|c|c|c|c|}
\hline Variables & Sample & Treated & Control & Difference & SE & t-stat \\
\hline \multirow{2}{*}{$\begin{array}{l}\text { Frequency of } \\
\text { visits }\end{array}$} & Unmatched & 2.82 & 1.60795455 & 1.21204545 & 0.149779121 & 8.09 \\
\cline { 2 - 7 } & ATT & 2.82 & 1.77 & 1.05 & 0.184573982 & 5.69 \\
\hline $\begin{array}{l}\text { Monthly health } \\
\text { care expenditure }\end{array}$ & Unmatched & 15.115 & 33.5662879 & -18.4512879 & 3.16134025 & -5.84 \\
\cline { 2 - 7 } & ATT & 15.115 & 29.87 & -14.755 & 5.05792214 & -2.92 \\
\hline $\begin{array}{l}\text { HHs awareness on } \\
\text { Family planning }\end{array}$ & Unmatched & 0.97 & 0.914 & 0.055 & .024 & 2.34 \\
\cline { 2 - 7 } & ATT & 0.97 & 0.91 & 0.06 & 0.03 & 1.77 \\
\hline
\end{tabular}

Source: own survey result, 2018

Table 13 reveals the results of the average treatment effects of community based health insurance on outcome variables by using different PSM algorithms. It indicates enrolling in community based health

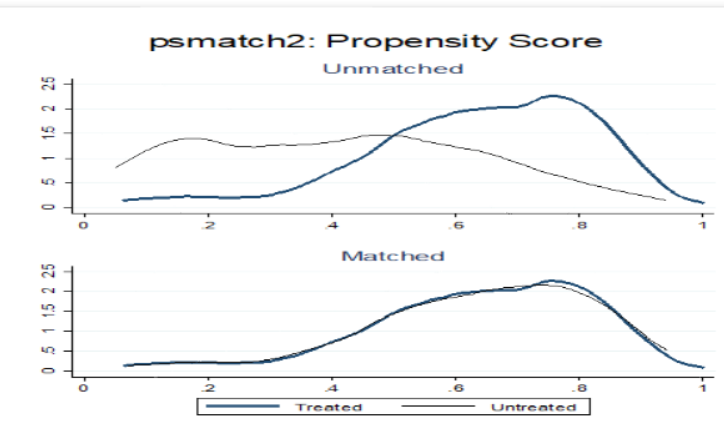

insurance scheme has a significant impact on households' frequency of visits to health facilities to access health care services, in reduction of health care costs and awareness on family planning.

Figure 1: pstest graph of samples, both matched and unmatched

Hence, the average frequency of visit of CBHI enrolled households is $1.05,1.12,1.12$, and 1.35 more than the average frequency of visit of not enrolled households by using NNM, KM, SM and RM, respectively and the results are statistically significant at 1 percent significant level. In terms of monthly health care expenditure, the treated groups have 14.75 birr, 17.96 birr, 17.45 birr and 11.84 birr less health care expenditure than non-treated groups by using NNM, KM, SM and RM, respectively and the results are statistically significant at 1 percent significant level. Furthermore, the number of CBHI enrolled HHs 


\section{International Journal of Research in Advent Technology, Vol.7, No.11, November 2019 \\ E-ISSN: 2321-9637 \\ Available online at www.ijrat.org}

who have awareness on family planning are $6,5.8,5.4$ and 7.5 percent more than the number of not enrolled HHs by using NNM, KM, SM and RM, respectively. Therefore, estimations by using four of the above matching methods indicated that enrolling in CBHI scheme has significantly increased health care utilization of households, reduced their monthly health care expenditures and increased their awareness on family planning.

Table 13: Average treatment effect on outcome variables by using different PSM algorithms

\begin{tabular}{|l|l|l|l|l|}
\hline Outcome variables & Matching Methods & ATT & S.E. & t-value \\
\hline \multirow{4}{*}{ Frequency of visit } & Nearest neighbor Matching & 1.05 & 0.18 & $5.72 * * *$ \\
\cline { 2 - 5 } & Kernel Matching & 1.12 & 0.16 & $7.22^{* * *}$ \\
\cline { 2 - 5 } & Stratification Matching & 1.12 & 0.16 & $7.2^{* * *}$ \\
\cline { 2 - 5 } & Radius matching & 1.35 & 0.293 & $4.6^{* * *}$ \\
\hline \multirow{4}{*}{$\begin{array}{l}\text { Monthly health care } \\
\text { expenditure }\end{array}$} & Nearest neighbor Matching & -14.75 & 5.08 & $-2.9 * * *$ \\
\cline { 2 - 5 } & Kernel Matching & -17.96 & 4.13 & $-4.35^{* * *}$ \\
\cline { 2 - 5 } $\begin{array}{l}\text { Awareness on family } \\
\text { planning }\end{array}$ & Stratification Matching & -17.45 & 4.28 & $-4.08^{* * *}$ \\
\cline { 2 - 5 } & Radius matching & -11.84 & 4.28 & $-2.77^{* * *}$ \\
\cline { 2 - 5 } & Kearest neighbor Matching & 0.06 & 0.03 & $1.76^{*}$ \\
\cline { 2 - 5 } & Kernel Matching & 0.058 & 0.03 & $2.35^{* * *}$ \\
\cline { 2 - 5 } & Radius matching & 0.054 & 0.026 & $2.05^{* *}$ \\
\hline
\end{tabular}

$*, * *, * * *$ statistically significant at 10, 5 and 1 percent significant level, respectively.

Source: own survey, 2018

\section{ESTIMATING THE IMPACT OF CBHI ON OUTCOME VARIABLES: USING ESR}

Estimating the effects of community based health insurance without conceiving heterogeneity effects among the households might bias the results. Furthermore, the effect of enrolling in community based health insurance might be confounded with another household characteristics and there could be selection bias by service providers. In order to overcome bias and inconsistency in the estimated results endogenous switching regression model is employed. It also accounts households` heterogeneity.

\section{A. The impact of $\mathrm{CBHI}$ on Health care utilization (Frequency of visit)}

The full information maximum likelihood method estimation result is presented in table 14, which estimates the results of endogenous switching regression model. The OLS estimation result is reported in column 2 of the table, which shows the determinants of frequency of visit to health facilities without accounting heterogeneity effects. According to the OLS regression result, livestock ownership increases the frequency of visit, on the other hand, the annual income affects it negatively, both are statistically significant at 5 and 10 percent levels, respectively. But the OLS estimate is biased because it considers enrollment in CBHI scheme is determined by exogenous characteristics, which ignores the endogenous factors which can affect the households' enrollment in CBHI scheme.

The $3^{\text {rd }}$ column reports the determinants of $\mathrm{CBHI}$ enrollment by using probit selection equation. The main determinants that affect the enrollment households to CBHI scheme are family size, asset ownership, HHs participation in social and religious positions. Age of $\mathrm{HH}$ head, social, political and religious participations, asset and livestock ownership, cropland size and family size increase the probability of participation in CBHI scheme but Sex of household head reduces the probability of enrollment in the scheme. As described above, the negative relationship between the treatment variable and sex implies that there is a gender bias in enrollment of the CBHI scheme. Column 3 and 4 of table 14 reports the results endogenous switching regression model for health care utilization (frequency of visit) both for CBHI members and non-members, respectively. As it can be seen from the result, there is a difference in coefficients of frequency of visit equation between treated and control groups, which shows that there is heterogeneity effect which can affect households enrollment in the scheme. While age and literacy levels of treated household heads have negative relationship with frequency of visit to health facilities, sex of treated household heads has positive relationship with health care utilization. 


\section{International Journal of Research in Advent Technology, Vol.7, No.11, November 2019 \\ E-ISSN: 2321-9637 \\ Available online at www.ijrat.org}

Table 15 reports the average frequency of visits in 3 months under actual and counterfactual conditions of CBHI member households (Cells a and c) and nonmember households (cells b and d), changing their membership positions. When we see the average frequency of visits of enrolled (cell a) and not-enrolled households (b), they have on average 2.82 and 1.61, respectively. Which implies that there is average difference of 1.21 mean difference between two groups. But this result may lead to wrong conclusions that enrolling in CBHI scheme increases health care utilization of households. With regard to counterfactual case (cell c), for households participating in CBHI scheme, the expected average frequency of visit of them would have been 1.93 , which is less by 0.89 , if they did not enroll to the scheme, which supports the findings of different studies conducted by (Mebratie, 2015) and (Ethiopian Health Insurance Agency, 2015). Similarly, the counterfactual case (cell d), for households not participating in CBHI scheme, the expected average frequency of visit of them would have been 0.81 , which is less by 0.8 , if they had enrolled to the scheme. Hence, participating in CBHI scheme significantly increases the average visits of those member households, in contrary, it does not improve the average frequency of visits of those non-member households even if they join the scheme. The heterogeneity effect of $\mathrm{CBHI}$ on health care utilization (TH) shows that CBHI member households are better off in utilizing health care services than non-member households even if the CBHI scheme was not there.

Table 14: parameter estimates of enrolling in CBHI and frequency of visit

\begin{tabular}{|c|c|c|c|c|c|c|c|c|}
\hline \multirow{4}{*}{ Variables } & \multirow{2}{*}{\multicolumn{2}{|c|}{$\begin{array}{l}\text { (1) } \\
\text { OLS }\end{array}$}} & \multirow{2}{*}{\multicolumn{2}{|c|}{ (2) }} & \multirow{2}{*}{ Endogen } & & \multicolumn{2}{|l|}{ (4) } \\
\hline & & & & & & IS switching & gression & \\
\hline & \multicolumn{2}{|c|}{ Frequency of visit } & \multicolumn{2}{|c|}{ CBHI (1/0) } & \multicolumn{2}{|c|}{ CBHI-1 } & \multicolumn{2}{|c|}{ CBHI-0 } \\
\hline & Coef. & $\mathrm{P}>|\mathrm{t}|$ & Coef. & $\mathrm{P}>|\mathrm{z}|$ & Coef. & $\mathrm{P}>|\mathrm{z}|$ & Coef. & $\mathrm{P}>|\mathrm{z}|$ \\
\hline Sex of HH head & 0.31 & 0.162 & -0.14 & 0.460 & 0.83 & $0.022 * *$ & -0.12 & 0.510 \\
\hline Age of $\mathrm{HH}$ head & -0.00 & 0.781 & 0.00 & 0.579 & -0.02 & $0.086 *$ & 0.00 & 0.699 \\
\hline Literacy of HH head & -0.16 & 0.370 & 0.05 & 0.746 & -0.72 & $0.010 * * *$ & 0.28 & 0.104 \\
\hline $\begin{array}{l}\text { HH political } \\
\text { participation }\end{array}$ & 0.17 & 0.444 & 0.10 & 0.598 & -0.04 & 0.908 & 0.10 & 0.641 \\
\hline HH social participation & 0.28 & 0.310 & 0.47 & $0.047 * *$ & 0.51 & 0.341 & -0.33 & 0.182 \\
\hline $\begin{array}{l}\mathrm{HH} \text { religious } \\
\text { participation }\end{array}$ & -0.04 & 0.888 & 0.69 & $0.003 * * *$ & -0.27 & 0.678 & -0.36 & 0.160 \\
\hline $\begin{array}{l}\text { Livestock ownership } \\
\text { (ETB) }\end{array}$ & 5.52 & $0.05 * *$ & 0.00 & 0.299 & 0.00 & $0.003 * * *$ & 0.00 & 0.234 \\
\hline Asset (ETB) & 0.00 & $0.05 * *$ & 0.00 & $0.087 *$ & 0.00 & 0.354 & 0.00 & 0.983 \\
\hline Cropland (hectare) & 0.12 & 0.196 & 0.09 & 0.237 & 0.11 & 0.428 & 0.04 & 0.674 \\
\hline Annual income (ETB) & -8.65 & $0.059 *$ & 0.00 & 0.798 & 0.00 & 0.165 & 0.00 & $0.042 * *$ \\
\hline Family size & & & 0.18 & $0.000 * * *$ & & & & \\
\hline constant & 1.58 & 0.000 & -2.15 & 0.000 & 2.61 & 0.132 & 1.89 & 0.000 \\
\hline
\end{tabular}

$*, * *, * * *$ significant at 10,5 and 1 percent of significance levels, respectively.

Source: own survey, 2018

Table 15: average frequency of visit, treatment and heterogeneity effect

\begin{tabular}{|l|l|l|l|}
\hline & \multicolumn{2}{|c|}{ Decision stage } & \multirow{2}{*}{ Treatment effects } \\
\hline & Enroll & Not enroll & \multirow{2}{*}{ TT $=0.89^{* * *}$} \\
\hline Enrolled in CBHI & a) 2.82 & c) 1.93 & TU $=-0.8 * * *$ \\
\hline Did not enroll in CBHI & d) 0.81 & b) 1.61 & $\mathrm{TH}=1.69 * * *$ \\
\hline Heterogeneity effect & BH1 $2.01 * * *$ & BH2 $=0.32 * * *$ & \\
\hline
\end{tabular}

$*, * *, * * *$ significant at 10,5 and 1 percent significance levels, respectively

Source: own survey, 2018 


\section{International Journal of Research in Advent Technology, Vol.7, No.11, November 2019 E-ISSN: 2321-9637 \\ Available online at www.ijrat.org}

\section{B. The impact of $\mathrm{CBHI}$ on Monthly health care expenditure of households}

Table 16 reports the analysis of the role of $\mathrm{CBHI}$ scheme on monthly health care expenditure of households using endogenous switching regression model estimated by full information maximum likelihood and OLS estimation techniques. The second column reveals that enrolling in CBHI scheme reduces the monthly health care expenditure of households by 19.75 birr, which is significant at 1 percent significance level. Being male (not significant) and having more family size (statistically significant at 5 percent significance level) increases the monthly health care expenditure while being literate (statistically significant at 5 percent significance level) and having more cropland reduces the monthly expenditure of households.

The third column shows the determinants of CBHI enrollment by using probit selection equation. The main determinants that affect the enrollment households to CBHI scheme are family size and HHs participation in social positions. Age of $\mathrm{HH}$ head, social participations, cropland size and family size increase the probability of participation in CBHI scheme but Sex of household head reduces the probability of enrollment in the scheme, which is align with the study conducted by (Ethiopian Health Insurance Agency, 2015). As described above, the negative relationship between the treatment variable and sex implies that there is a gender bias in enrollment of the CBHI scheme.

Column 3 and 4 report the results endogenous switching regression model for health care expenditure both for CBHI members and nonmembers, respectively. As it can be seen from the result, there is a difference in coefficients of health care expenditure equation between treated and control groups, which shows that there is heterogeneity effect which can affect households' enrollment in the scheme. While age, sex and literacy levels of treated household heads have negative relationship with health care expenditure, family size has positive relationship with monthly expenditure of households. On the other hand, literacy level of non-treated group has negative relationship with monthly expenditure of households and the more the family size they have, the more monthly expenditure they will have.

Table 17 reports the average monthly expenditure under actual and counterfactual conditions of CBHI member households (Cells a and c) and non-member households (cells $b$ and d), changing their membership positions. When we see the monthly expenditure of enrolled (cell a) and not-enrolled households (b), they have on average 15.12 birr and 33.56 birr, respectively. Which implies that there is an average 18.44-birr difference between two groups. But this result may lead to wrong conclusions that enrolling in CBHI scheme reduces health care utilization cost.

In terms of counterfactual case (cell c), for households participating in CBHI scheme, the expected average monthly expenditure of them would have been 23.02 birr, which is 7.9 birr more, if they did not enroll to the scheme. Similarly, the counterfactual case (cell d), for households not participating in CBHI scheme, the expected average monthly health care expenditure of them would have been 43.38 birr, which is 9.82 birr more, if they had enrolled to the scheme. Hence, participating in CBHI scheme significantly reduces the average monthly health care expenditures of those member households. The heterogeneity effect of CBHI on health care expenditure (TH) shows negative, which implies that CBHI scheme will have a stronger effect on households who did not join the scheme than those member households. This result supports the findings of different studies by (Preker, et al., 2002) (Ethiopian Health Insurance Agency, 2015) (Mebratiea, Sparrow, Alemu, \& Bedi, 2013). 
International Journal of Research in Advent Technology, Vol.7, No.11, November 2019

E-ISSN: 2321-9637

Available online at www.ijrat.org

Table 16: parameter estimates of enrolling in CBHI and monthly health care expenditure of HHs

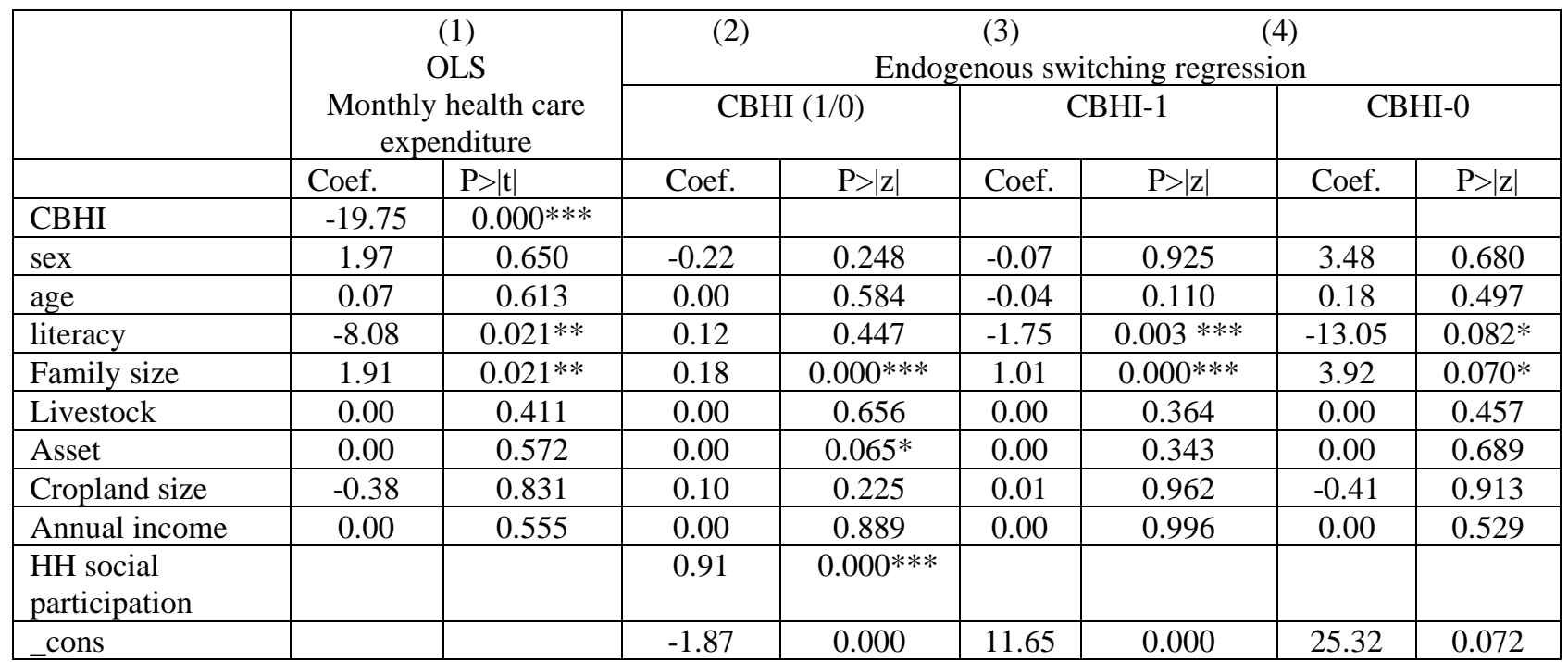

$*, * *, * * *$ significant at 10,5 and 1 percent of significance levels, respectively.

Source: own survey, 2018

Table 17: average monthly expenditure, treatment and heterogeneity effect

\begin{tabular}{|l|l|l|l|}
\hline & \multicolumn{2}{|c|}{ Decision stage } & \multirow{2}{*}{ Treatment effects } \\
\hline & Enroll & Not enroll & c) 23.02 \\
\hline Enrolled in CBHI & a) 15.12 & b) 33.56 & TT $=-7.9 * * *$ \\
\hline Did not enroll in CBHI & d) 43.38 & BH2 $=-10.54 * * *$ & TU $=9.82 * * *$ \\
\hline Heterogeneity effect & BH1=-28.26*** & TH $=-17.72 * * *$ \\
\hline
\end{tabular}

$*, * *, * * *$ significant at 10,5 and 1 percent significance levels, respectively

\section{The impact of CBHI on family planning awareness}

Table 17 reports the analysis of the role of CBHI scheme on households` awareness on family planning using endogenous switching regression model estimated by full information maximum likelihood and probit estimation techniques. The second column shows that being male decreases the awareness of households by 20.9 percent and older people have less awareness than younger household heads. Being married and literate increases the awareness of households by 68.4 and 14.1 percent, respectively.

The third column shows the determinants of CBHI enrollment by using probit selection equation. The main determinants that affect the enrollment households to CBHI scheme are $\mathrm{HHs}$ participation in social and religious positions. Age of $\mathrm{HH}$ head, literacy, cropland size, marital status (being married) increase the probability of participation in CBHI scheme but Sex of household head (being male) reduces the probability of enrollment in the scheme. As described above, the negative relationship between the treatment variable and sex implies that there is a gender bias in enrollment of the CBHI scheme. 
Table 18: parameter estimates of enrolling in CBHI and awareness of HHs on family planning

\begin{tabular}{|c|c|c|c|c|c|c|c|c|}
\hline \multirow{4}{*}{ Variables } & \multirow{3}{*}{\multicolumn{2}{|c|}{$\begin{array}{c}(1) \\
\text { Probit model } \\
\text { Information on FP }\end{array}$}} & \multirow{2}{*}{\multicolumn{6}{|c|}{$\begin{array}{cc}\text { (3) } & (4) \\
\text { Endogenous Switching Regression }\end{array}$}} \\
\hline & & & & & & & & \\
\hline & & & \multicolumn{2}{|c|}{ CBHI $(1 / 0)$} & \multicolumn{2}{|c|}{$\mathrm{CBHI}=0$} & \multicolumn{2}{|c|}{$\mathrm{CBHI}=1$} \\
\hline & Coef. & $\mathrm{P}>|\mathrm{z}|$ & Coef. & $\mathrm{P}>|\mathrm{z}|$ & Coef. & $\mathrm{P}>|\mathrm{z}|$ & Coef. & $\mathrm{P}>|\mathrm{z}|$ \\
\hline Age of HH head & -0.032 & $0.007 * * *$ & 0.007 & 0.287 & -0.003 & $0.047 * *$ & -0.002 & 0.165 \\
\hline Sex of HH head & -0.209 & 0.662 & -0.232 & 0.415 & -0.039 & 0.618 & 0.000 & 0.992 \\
\hline Age to give birth & -0.194 & $0.000 * * *$ & 0.018 & 0.528 & -0.032 & $0.000 * * *$ & -0.011 & $0.041 * *$ \\
\hline literacy & 0.141 & 0.662 & 0.158 & 0.309 & 0.015 & 0.724 & 0.018 & 0.492 \\
\hline Marital status & 0.684 & 0.144 & 0.372 & 0.223 & 0.063 & 0.437 & 0.057 & 0.312 \\
\hline Asset (ETB) & 0.000 & 0.246 & 0.000 & 0.264 & 0.000 & 0.704 & 0.000 & 0.340 \\
\hline Cropland (hectare & -0.044 & 0.738 & 0.102 & 0.209 & -0.011 & 0.604 & -0.002 & 0.861 \\
\hline Annual income (ETB) & 0.000 & $0.001 * * *$ & 0.000 & 0.700 & 0.000 & $0.005^{* *}$ & 0.000 & $0.01 * * *$ \\
\hline Livestock (ETB) & 0.000 & 0.349 & 0.000 & 0.589 & 0.000 & 0.898 & 0.000 & 0.445 \\
\hline HH social participation & & & 0.488 & $0.031 * *$ & & & & \\
\hline HH religious participation & & & 0.912 & $0.00 * * *$ & & & & \\
\hline Constant & 6.932 & $0.00 * * *$ & -2.227 & $0.001 * * *$ & 1.627 & $0.0 * * *$ & 1.215 & $0.0 * * *$ \\
\hline
\end{tabular}

$*, * *, * * *$ significant at 10,5 and 1 percent significance levels, respectively

Source: own survey, 2018

Table 19: Awareness on family planning, treatment and heterogeneity effect

\begin{tabular}{|c|c|c|c|}
\hline & \multicolumn{2}{|c|}{ Decision stage } & \multirow{2}{*}{ Treatment effects } \\
\hline & Enroll & Not enroll & \\
\hline Enrolled in CBHI & a) 0.97 & c) 0.839 & $\mathrm{TT}=0.131 * * *$ \\
\hline Did not enroll in $\mathrm{CBHI}$ & d) 0.799 & b) 0.915 & $\mathrm{TU}=-0.116 * * *$ \\
\hline Heterogeneity effect & $\mathrm{BH} 1=-0.171 * * *$ & $\mathrm{BH} 2=-0.075 * * *$ & $\mathrm{TH}=0.247 * * *$ \\
\hline
\end{tabular}

$*, * *, * * *$ significant at 10,5 and 1 percent significance levels, respectively

Source: own survey, 2018

Column 3 and 4 report the results endogenous switching regression model for family planning awareness both for not enrolled and enrolled households, respectively.

As it can be seen from the result, there is a difference in coefficients of information on family planning equation between treated and control groups, which shows that there is heterogeneity effect which can affect households' enrollment in the scheme. While age, sex and cropland ownership of non-treated household heads have negative relationship with awareness on family planning, literacy level and marital status has positive relationship with households' awareness on family planning. But sex of $\mathrm{HH}$ head on the treated group has almost no effect (nearly zero).

Table 19 reports the awareness of family planning under actual and counterfactual conditions of CBHI member households (Cells a and c) and non-member households (cells b and d), changing their membership positions. When we see the awareness of enrolled (cell a) and not-enrolled households (b), they have on average 97 percent and 91.5 percent, respectively, which implies that there is an average 5.5 percent difference between two groups. But this result may lead to wrong conclusions that enrolling in $\mathrm{CBHI}$ scheme increases the awareness of households on family planning.

In terms of counterfactual case (cell c), for households participating in CBHI scheme, the expected awareness of households on family planning would have been 83.9 percent, which is 13.1 percent less, if they did not enroll to the scheme. Similarly, the counterfactual case (cell d), for households not participating in CBHI scheme, the awareness of households on family planning would have been 79.9 percent, which is 11.6 percent more, if they had enrolled to the scheme. 


\section{International Journal of Research in Advent Technology, Vol.7, No.11, November 2019 \\ E-ISSN: 2321-9637 \\ Available online at www.ijrat.org}

Hence, participating in CBHI scheme significantly increase the awareness of those member households which supports the study by (Naik, Morgan, \& Wright, 2014). The heterogeneity effect of CBHI on awareness

\section{CONCLUSIONS}

The study analyzed the effects of community based health insurance scheme in North Achefer Woreda. These effects are in terms of health care utilization both frequency of visit to health facilities to access health care services, awareness level on family planning and monthly health care expenditure. To estimate effects the study used both PSM and ESR models and the study has shown results by using both models. The result of propensity score matching method shows that there is a significant difference between CBHI enrolled (treated) and not-enrolled (controls) groups in terms of health care utilization and monthly health care expenditure. The t-test result of the impact of community based health insurance before matching proved that the mean difference between treated and control groups, in terms of health care utilization and monthly health care expenditure, are statistically significant at 1 percent significance level. The average treatment effect on the treated (ATT) result after matching shows that there is a statistically significant difference between treated and control groups, in terms of health care utilization and monthly health care expenditure. Since kernel matching is better in comprising of larger matched samples, its result is better than the other PSM algorithms. Thus, enrolled households have 1.2 more frequency of visit and 17.96 birr less monthly health care expenditure than not-enrolled households. There awareness on family planning is 5.8 percent more than not enrolled households. PSM is used to extract a comparable pair of treatment-comparison households in a non-random program setup and in the absence of base line data. It can also reduce selection bias in some extent, but not does not totally solve the selection bias and does not estimate the counterfactuals.

Hence, endogenous switching regression model is employed in this study to overcome the potential biases in estimating endogenously determined outcome variables. The biases from observable and observable heterogeneities among households which might affect CBHI or other variables in determining health care utilization of households. Since ESR estimation has been conducted by controlling the sources of biases, the results are more robust and the of households on family planning shows that CBHI member households are better off in accessing information on family planning than non-member households even if the CBHI scheme was not there.

conclusions drawn are reliable. The result of ESR estimation shows that the decision to enroll in community based health insurance is influenced by household characteristics. It is positively affected by literacy level of household head, household's participation on political, social and religious positions, livestock ownership, asset ownership, size of land (cropland), family size and annual income. On the other hand, it has negative relationship with sex, which tells us that females are more likely to participate in community based health insurance.

In addition, the analysis reveals that members of community based health insurance have more frequency of visit to health facilities and have better awareness on family planning than non-members. Furthermore, the analysis tells us that enrolling in community based health insurance reduces their monthly health care expenditure by 19.75 birr while having more family size will incur the household additional health care cost. The analysis after accounting for household heterogeneity shows that enrolling in CBHI scheme indeed improved frequency of visit to health facilities and level of awareness on family planning. It also reduced the monthly health care cost of households significantly. However, the results depicted that the counterfactuals of not enrolled households would not have had the expected impacts, which the reason was not addressed by this study.

Finally, the study concludes that the implementation of community based health insurance has brought an impact on households' health care utilization, awareness on family planning and in reduction of health care costs. The heterogeneity effect of CBHI on health care utilization $(\mathrm{TH})$ shows that $\mathrm{CBHI}$ member households are better off in utilizing health care services than non-member households even if the CBHI scheme was not there. Therefore, this study recommends the respective bodies to focus on awareness creation for the community on health care utilization thereby they can develop health seeking behavior and can use CBHI as an opportunity to get health care services with low cost. 


\section{International Journal of Research in Advent Technology, Vol.7, No.11, November 2019 \\ E-ISSN: 2321-9637 \\ Available online at www.ijrat.org}

\section{REFERENCES}

[1] Abaerei, A. A., Ncayiyana, J., \& Levin, J. (2017). Health-care utilization and associated factors in Gauteng province, South Africa Faculty of Health Sciences, School of Public Health, University of the Witwatersrand, South Africa; College of Health and Medical Sciences, Haramaya University, Ethiopia.

[2] Arhin-Tenkorang, D. (2001). Health Insurance for the Informal Sector in Africa : Design Features, Risk Protection, and Resource Mobilization. HNP discussion paper series. Washington, DC: World Bank, . () World Bank. https://openknowledge.worldbank.org/h.

[3] Bazie, G., \& Adimassie, M. (2017). Modern health services utilization and associated factors in North East Ethiopia. PLoS ONE 12(9): e0185381.

[4] Bocher, T. F., Alemu, B. A., \& Kelbore, Z. G. (2017). Does access to credit improve household welfare? Evidence from Ethiopia using endogenous regime switching regression. African Journal of Economic and Management Studies, Vol. 8 Iss 1 pp. 51 - 65

[5] Carrin, G. (2003). Community based Health Insurance Schemes in Developing Countries: facts, problems and perspectives, , WORLD HEALTH ORGANIZATION. GENEVA

[6] Donabedian, A. (1973). Aspects of medical care Administration: specifying requirements of health care cambridge. Harvard University press.

[7] Ekman, B. (2004). Community-Based Health Insurance in LowIncome Countries: A Systematic Review of the Evidence. Health policy and planning. . 19. 249-70. 10.1093/heapol/czh031.

[8] Escobar, M.-L., Griffin, C. C., \& Shaw, R. P. (2010). Impact of health insurance in low- and middle-income countries. Washington DC: BROOKINGS INSTITUTION PRESS

[9] Ethiopian Health Insurance Agency. (2015). Evaluation of Community-Based Health Insurance Pilot Schemes in Ethiopia: Final Report. . Addis Ababa, Ethiopia.

[10] Falco, S. D., Veronesi, M., \& Yesuf, M. (2010). Does adaptation to climate change provide food security? A micro-perspective from Ethiopia. Centre for Climate Change Economics and Policy Working Paper No. 22, Grantham Research Institute on Climate Change and the Environment Working Paper No. 19

[11] FMOH. (2011). The Federal Democratic Republic of Ethiopia Ministry of Health, 2015. Health Sector Development Plan 2010/11 - 2014/15. Addis Ababa, Ethiopia.

[12] FMOH. (2014). Ethiopia's Household Health Services Utilization and Expenditure Survey Briefing Notes. . Addis Ababa, Ethiopia.

[13] FMOH. (2016). Ethiopian health sector transformation plan (HSTPI) annual report. Addis Ababa: Federal Ministry of Health.

[14] Garg, C. C., \& Karan, A. K. (2009). Reducing out-of-pocket expenditures to reduce poverty: a disaggregated analysis at ruralurban and state level in India, Health Policy and Planning . 24:116128 doi:10.1093/heapol/czn046.

[15] Geitona, M., Zavras, D., \& Kyriopoulos, J. (2007). Determinants of healthcare utilization in Greece: Implications for decision-making,. The European Journal of General Practice, 13:3, 144-150, DOI: 10.1080/13814780701541340

[16] Ghimire, B. R., \& KotaniA, K. (2015). counterfactual experiment on the effectiveness of plastic ponds for smallholder farmers: A case of Nepalese vegetable farming, . Research Center for Social Design Engineering, Kochi University of Technology, Social Design Engineering Series, SDES-2015-18.

[17] Heckman, J. J., LaLonde, R. J., \& Smith, J. A. (1999). The Economics and Econometrics of Active Labor Market Programs. University of Chicago, Michigan State University, University of Western Ontario.
18] Humuza, J. (2011). Coexistence of Performance Based Financing $(P B F)$ and Community Based Health Insurance (CBHI): Rwanda Experience." Conference presentation.

[19] Jakab, M., \& Krishnan, C. (2001). Community Involvement in Health Care Financing : A Survey of the Literature on the Impact, Strengths, and Weaknesses. Washington, DC: HNP discussion paper series; World Bank, . () World Bank.

[20] Jutting, J. P. (2001). THE IMPACT OF HEALTH INSURANCE ON THE ACCESS TO HEALTH CARE AND FINANCIAL PROTECTION IN RURAL DEVELOPING COUNTRIES, The Example of Senegal.

[21] Kalisa, I., Musange, S., Collins, D., Saya, U., \& Kunda, T. (2015) The Development of Community-Based Health Insurance in Rwando - Experiences and Lessons. University of Rwanda College of Medicine and Health Sciences - School of Public Health, Kigali, Rw.

[22] Khandker, S. R., Koolwal, G. B., \& Samad, H. A. (2010). Handbook on Impact Evaluation: Quantitative Methods and Practices, . the World Bank, Washington DC.

[23] Lokshin, M., \& Sajaia, Z. (2004). "Maximum Likelihood Estimation of Endogenous Switching Regression Models,. Stata Journal 4(3):282-289.

[24] Maeda, A., Araujo, E., Cashin, C., Harris, J., Ikegami, N., \& Reich, M. R. (2014). Universal Health Coverage for Inclusive and Sustainable Development: A Synthesis of 11 Country Case Studies, Washington DC.: World Bank.

[25] Masiye, F., \& Kaonga, O. (2016). Determinants of healthcare utilisation and out-of-pocket payments in the context of free public primary healthcare in Zambia. Int $\mathrm{J}$ Health Policy Manag. 2016;5(12):693-703. doi:10.15171/ijhpm.2016.65.

[26] Mathauer, I., Mathivet, B., \& Kutzin, J. (2017). Free health care policies: opportunities and risks for moving towards UHC.: World Health Organization; Geneva: Licence: CC BY-NC-SA 3.0 IGO.

[27] Mebratie, A. D. (2015). ESSAYS ON EVALUATING A COMMUNITY BASED HEALTH INSURANCE SCHEME IN RURAL ETHIOPIA.

[28] Mebratiea, A. D., Sparrow, R., Alemu, G., \& Bedi, A. S. ( 2013). Community-Based Health Insurance Schemes: A Systematic Review

[29] Naik, R., Morgan, L., \& Wright, J. (2014). The Role of Health Insurance in Family Planning POPULATION REFERENCE BUREAU, policy brief.

[30] Organization, World Health. (2005). Sustainable Health Financing, Universal Coverage and Social Health Insurance. Geneva.

[31] Panda, P., Dror, I., Koehlmoos, T., Hossain, S., John, D., Khan, J., $\&$ Dror, D. (2016). Factors affecting uptake of voluntary and community-based health insurance schemes in low-and middle income countries: a systematic review, 3ie Systematic Review 27. I. London:: nternational Initiative for Impact Evaluation (3ie).

[32] Preker, A. S., Carrin, G., Dror, D., Jakab, M., Hsiao, W., \& Dyna Arhin-Tenkorang. (2002). Effectiveness of community health financing in meeting the cost of illness $*, 2002$, . Bulletin of the World Health Organization 2002;80:143-150.

[33] Raiz, L., Hade, E., Hayes, W., Root, E., Wexler, R., Bennett, R., \& Brown, N. (2016). SOCIAL DETERMINANTS OF HEALTH, ACCESS TO HEALTH CARE AND HEALTH CARE UTILIZATION, College of Social Work Center for Biostatistics, Dept.Dept. of Biomedical Informatics, College of MedicineThe Ohio State University Wexner Medical Center. 


\section{International Journal of Research in Advent Technology, Vol.7, No.11, November 2019 \\ E-ISSN: 2321-9637 \\ Available online at www.ijrat.org}

[34] Rosenbaum, P., \& and Rubin, D. (1983). The Central Role of the Propensity Score in Observational Studies for Causal Effects", Biometrika, 70, 1, 41-55.

[35] Tabor, S. R. (2005). Community-Based Health Insurance and Social Protection Policy, Social Protection Unit Human Development Network. The World Bank, Social Protection Discussion Paper Series, No. 0503

[36] Umeh, C. A., \& Feeleya, F. G. (2017). Inequitable Access to Health Care by the Poor in Community-Based Health Insurance Programs: A Review of Studies From Low- and Middle-Income Countries.

[37] United Nations. (2015). Resolution 70/1. Transforming our world: the 2030 Agenda for Sustainable Development. In: Seventieth session of the United Nations General Assembly. New York.

[38] WHO. (2015). Global Malaria report. World Health Organization.

[39] WHO. (2015). Global Tuberculosis report. World Health Organization.

[40] WHO. (2015). Tracking universal health coverage: first global monitoring report. World Health Organization and the World Bank.

[41] WHO. (2016). World health statistics: monitoring health for the SDGs, sustainable development goals. World Health Organization.
[42] WHO. (2017). Family planning/contraception: Fact sheet. WHO media center

[43] WHO and World Bank. (2017). Tracking universal health coverage: 2017 global monitoring report. World Health Organization and International Bank for Reconstruction.

[44] World Health Organization. (2010). The world health report. Health systems financing: the path to universal coverage. Geneva.

[45] World Health Organization. (2013). Handbook on health inequality monitoring: with a special focus on low- and middle income countries. Geneva.

[46] Wright, J., Bhuwanee, K., Patel, F., Holtz, J., Bastelaer, T. v., \& Eichler, R. (2016). Financing of Universal Health Coverage and Family Planning: A Multi-Regional Landscape Study and Analysis of Select West African Countries. Report prepared by the Health Finance \& Governance Project. . Washington, DC: United States Agency for International Development.

[47] Yilma, Z., Mebratie, A., Sparrow, R., Dekker, M., Alemu, G., \& Bedi, A. S. (2014). Impact of Ethiopia's Community Based Health Insurance on Household Economic Welfare .

\section{AUTHORS PROFILE}

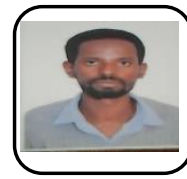

Lesanework Alemu Abenet, Ethiopian Food and

Drug Authority, Ethiopia

Author-2

Dr. Bamlaku Alamirew Alemu, Addis Ababa

University, Ethiopia

Author-3

Migbaru Alamirew, Yom Institute of Economic

Development, Ethiopia 